\title{
ASSOCIATION BETWEEN DOMINANT TREES SPECIES IN LOWLAND TROPICAL FOREST (EDUCATION FOREST OF JAMBI UNIVERSITY)
}

\author{
NURSANTI $^{1)}$, RIZKY AYU HARDIYANTI ${ }^{1)}$, AND ADE ADRIADI ${ }^{2 *}$ \\ 1) Jurusan Kehutanan Fakultas Pertanian, Universitas Jambi, Mendalo Darat Jambi, 36361, Indonesia \\ 2) Prodi Biologi Fakultas Sains dan Teknologi, Universitas Jambi, Mendalo Darat Jambi, 36361, Indonesia \\ *Email: adeadriadi@unja.ac.id
}

Accepted November 05, 2020 / Approved February 23, 2021

\begin{abstract}
Lowland forest vegetation can still be found on the Jambi University Campus, namely at the Jambi Mendalo University Educational Forest (HPUJM). Jambi University Educational Forest is administratively located in Mendalo Indah Village, Jambi Luar Kota District, Muaro Jambi Regency, Jambi Province. Vegetation communities are formed by the presence and interaction of the various types of plants that compose them. The form of interaction between plant species in a community is called an association. Associations can be in the form of positive associations and negative associations. This research was conducted to know the association between dominant tree species. This study used a purposive sampling method by determining a sampling area of $9600 \mathrm{~m} 2$ or 0.96 ha measuring $160 \mathrm{~m} x 60 \mathrm{~m}$, divided into 24 sub-plots, each measuring $20 \mathrm{~m} x 20 \mathrm{~m}$. Species having an Importance Value Index (IVI) of $\geq 10 \%$ were used as the association analysis. The $2 x 2$ contingency table was used to analyze whether or not associations were present between tree species. The results showed, of 15 dominant tree combinations, there were only 4 associated combinations, namely the association between Aporosa lucida and Vitex pinnata, the association between Endospermum diadenum and V.pinnata, the association of Litsea ferruginea with Gironniera diadenum, the association of L. ferruginea with V.pinnata.
\end{abstract}

Key words: association, dominant tree, lowland forest

\section{INTRODUCTION}

Lowland tropical rain forest is a habitat of diverse plant species including trees. The main characteristics of lowland tropical rain forest ecosystem are that there is an enormous bunch of tall tress in a wide area and many of them are rare trees, especially from the Dipterocarpaceae family that is mostly categorized as species threatened with extinction (Clark et al., 1999). Biodiversity on tropical forest is influenced by biotic and abiotic factors such as humidity and air temperature, chemical and physical properties of soil, fertility status of soil, sunlight intensity, topography, and parent material of soil. The biotic factors include the presence of other types of plants including lianas, epiphytes, stranglers, parasitic plants, shrubs, herbs, etc. The types of trees that grow in lowland tropical rain forests can still be found on Jambi University Campus, that is at the Education Forest of Jambi Mendalo University (HPUJM). This education forest area is a habitat for the protected primate that is gray langur (Presbitis cristata) (Subagyo et al., 2008) as well as habitats for 46 species of birds from 18 families (Putra, 2016).

A community will be formed by the presence of various types of plants that is interacting and forming symbiosis with each other. One of the forms of interaction between plant species in a community is called association. Association in an ecological system is a distinctive and unique form of community. Association between two types of trees can be categorized into positive association or negative association. If a type of flora is not present together, then it is called as negative association (McNaughton and Wolf, 1992).

A plant community that is consisted of various types of plants allows for the interaction between species in the community. For example, there are plants that compete for food and light, or plants living in symbiosis with other plants for nutrition or shade, such as various types of parasites or semi-tolerant plants that need shade during their seedling and sapling stages, but they need light when entering the pole and sapling stage.

Several previous studies that have been carried out in the HPUJM area are studies on population and daily behavior of primate, studies on bird species diversity, studies on indigenous mycorrhizae, and studies on microclimate and carbon content. This area is a habitat of the protected primate group, gray langur (Presbytis cristata) (Subagyo, 2008) as well as habitats for 46 species of birds from 18 families (Putra, 2016).

Vegetation studies, especially on association of tree species composition in the HPUJM area have not been carried out, so it is important to conduct this study to collect basic data for general knowledge enrichment and HPUJM management in particular. The objective of this study is to identify the association between dominant tree species in HPUJM.

\section{RESEARCH METHOD}

This study was carried out in a lowland tropical rain forest ecosystem in the Education Forest area of the University of Jambi, on Mendalo Campus, at Jalan Lintas 
Jambi-Muaro Bulian Km 15. HPUJM is administratively located in Mendalo Indah Village, Jambi Outer City District, Muaro Jambi Sub District, Jambi Province. In general, the topography of HPUJM area ranges from flat to wavy. The air temperature ranges from $30-31$ degress Celcius with air humidity of $54-65 \%$ during the day time (Nursanti and Swari, 2013). Vegetation data collection was carried out in April 2020.

Materials in this study were trees in HPUJM with a diameter at breast height $(d b h)$ of $\geq 10 \mathrm{~cm}$ or categorized as pole and tree pests (stadia) (Soerianegara and Indrawan, 1983), 70\% alcohol, newspaper, clear plastic, masking tape, and label. Tools used included ladder, scissors, sample presses, oven, spray bottle, and camera.

Sampling was done using the purposive sampling method in HPUJM where the condition of the tree composition represents the parameters of the structure and tree composistion of lowland forest. Vegetation analysis used a single plot method (Rugayah et al., 2005), with a study plot size of $9600 \mathrm{~m}^{2}$, which is a permanent plot of the Jambi University Forestry Study Program. The plot was divided into 24 plots of $20 \times 20$ meters each. The HPUJM area as a population is $11 \mathrm{Ha}$, while the sample unit area was $9600 \mathrm{~m}^{2}$ or $0.96 \mathrm{Ha}$. Therefore, the sampling intensity was $8.7 \%$.

The vegetation data collected consisted of the scientific name of each tree species, the number of individuals of existing each species, the number of plots found by tree species, and the breast at height diameter $(d b h)$. All tree species samples were sent to ANDA Herbarium, Faculty of Biology, Andalas University, Padang to be identified by plant sample identification experts. The Herbarium making referred to Partomihardjo et al. (2004).

The Importance Value Index described the dominant tree species in the study area.

The formula for calculating IVI is as follows:

$\mathrm{INP}=\mathrm{FR}+\mathrm{KR}+\mathrm{DR}$

$\mathrm{INP}=$ Importance Value Index $(\%)$

$\mathrm{FR}=$ Relative Frequency $(\%)$

$\mathrm{KR}=$ Relative Density $(\%)$

$\mathrm{DR}=$ Relative Dominance $(\%)$

- Density of a species used the formula:

$\mathrm{K}(\mathrm{btg} / \mathrm{ha})=$ Number of a species $($ individual/Ha)

Total area sampled

- Relative density (KR) formula : $\mathrm{KR}(\%)=\frac{\text { Density of a species }}{\text { Density of all species }} \times 100 \%$

- Frequency of as species used the formula:

$\mathrm{F}=\underline{\text { Area of plots in which a species occurs }}$ Total area sampled

- Relative Frequency (FR) formula :

$\mathrm{FR}(\%)=\underline{\text { Frequency of a species }} \times 100 \%$

Total frequency of all specied

- Dominance of a species used the formula:

$\mathrm{D}\left(\mathrm{m}^{2} / \mathrm{ha}\right) \quad=$ Total basal area of a species

Total area sampled
- Relative Dominance (DR) formula :

DR $(\%) \quad=$ Dominance of a species $\times 100 \%$

Total Dominance of all area

The association analysis of tree species dominating the study area was carried out on the main composing tree species of lowland tropical rain forest in HPUJM having the Importance Value Index score of $10 \%$. Analysis of the presence or absence of association was done using the Contingency Table $2 \times 2$ formulated by Greig-Smith (1983). The presence and absence of association between the dominant tree species in the forest area was then calculated using Chi-square $\left(\mathrm{x}^{2}\right)$ (Ludwig and Reynolds, 1988). If the value of $\mathrm{x}^{2}$ count $>x^{2}$ table, it means the association is significant. If $x^{2}$ count $<x^{2}$ table, it means (the association is not significant). The $\mathrm{x}^{2}$ table, where the free degree is 1 (one) at the significance level of $5 \%$ has a value of 3.84. Chisquare Test formulation is as follows:

$$
\text { Chi-square }\left(\mathrm{x}^{2}\right) \text { count }=\frac{N(a d-b c)^{2}}{(a+b)(a+c)) c+d)(b+d)}
$$

$\mathrm{a}=$ number of observation points containing type $\mathrm{A}$ and type B

$\mathrm{b}=$ number of observation points containing type A only

$\mathrm{c}=$ number of observation points containing type B only

$\mathrm{d}=$ number of observation points do not contain type $\mathrm{A}$ and type $\mathrm{B}$

$\mathrm{N}=$ number of observation points

Next, the strength of an association is calculated using the following formula:

$$
\mathrm{E}(\mathrm{a})=\frac{(a+b)(a+c)}{N}
$$

The notation used has the same meaning as the previous formulation. Based on this formula, there are two types of associations, positive association and negative association.

(1) An association is + (positive), if an a value $>\mathrm{E}$ (a).

(2) An association is - (negative), if an a value $<\mathrm{E}$ (a).

The degree of association strength between the two tree species in the study location was measured using Jaccard Index. The strength of association as measured by the association index value was within the range of 0 1 . If the association index value approaching 1 , it means that the relationship between the two dominant tree species is stronger (Ludwiq and Reynold, 1988).

\section{RESULT AND DISCUSSION}

The results of data analysis showed that $E$. diadenum from the euphorbiaceae family dominated HPUJM stands, with Importance Value Index (IVI) of $17.09 \%$ (Table 1), HPUJM is a representative of the lowland tropical rain forest ecosystem whose floristic composition is consisted of 32 families of trees. In addition to $E$. diadenum, there were six other trees dominating with IVI $\geq 10 \%$, which were pulai / Alstonia scholaris (INP 16.47\%), siluk / Gironniera nervosa (INP 
$15.29 \%$ ), leban / Vitex pinnata (INP 14.77\%), pelangas / Aporosa lucida (INP 13.65\%), Litsea ferruqinea $(13.55 \%)$ merapuyan / Rhodamnia cinerea (INP $11.80 \%$ ), respectively. Other tree species with an INP above 5\% were Aglaia sp 001 (9.41\%), Aidia racemosa (5.64\%), Bhesa paniculata (6.71\%), Garcinia parvifolia (9.69\%), Ixonanthes icosandra (5.46\%), Koompassia malaccensis (5.36\%), Litsea firma (7.24\%), Santiria griffithii (7.11\%), Porterandia anisophylla (6.86\%), and Syzygium sp 001 (5.85\%).

Based on Table 1. regarding the types of composing trees in the HPUJM, the followings are some pictures of these tree types. The calculation results of $\mathrm{X}^{2}$ to determine the presence and absence of association between dominant trees in HPUJM are presented in Table 2.

Table 1. Density, frequency, dominance and importance value index (INP) of tree composistion in Education Forest of Jambi Mendalo University.

\begin{tabular}{|c|c|c|c|c|c|c|}
\hline No & Latin Name & Family & $\begin{array}{l}\text { Relative } \\
\text { Density }\end{array}$ & $\begin{array}{l}\text { Relative } \\
\text { Frequency }\end{array}$ & $\begin{array}{c}\text { Relative } \\
\text { Dominance }\end{array}$ & IVI \\
\hline 1. & $\begin{array}{l}\text { Endospermum } \\
\text { (Miq.) Airy Shaw }\end{array}$ & Euphorbiaceae & 3.94 & 4.76 & 8.39 & 17.09 \\
\hline 2. & Alstonia scholaris (L.) R.Br. & Apocynaceae & 5.51 & 5.36 & 5.60 & 16.47 \\
\hline 3. & Gironniera nervosa Planch. & Cannabaceae & 6.30 & 4.76 & 4.23 & 15.29 \\
\hline 4. & Vitex pinnata $\mathrm{L}$. & Lamiaceae & 6.69 & 4.17 & 3.91 & 14.77 \\
\hline 5. & Aporosa lucida (Lindl.)Baill. & Phyllanthaceae & 6.30 & 4.76 & 2.59 & 13.65 \\
\hline 6. & Rhodamnia cinerea Jack & Myrtaceae & 4.72 & 3.57 & 3.51 & 11.80 \\
\hline 7. & $\begin{array}{l}\text { Aidia racemosa (Cav.) } \\
\text { Tirveng. }\end{array}$ & Rubiaceae & 2.76 & 2.38 & 0.50 & 5.64 \\
\hline 8. & Aglaia sp 001 & Meliaceae & 4.33 & 3.57 & 1.52 & 9.42 \\
\hline 9. & $\begin{array}{l}\text { Antidesma } \quad \text { ghaesembilla } \\
\text { Gaertn. }\end{array}$ & Phyllanthaceae & 0.39 & 0.60 & 0.30 & 1.29 \\
\hline 10. & Antidesma sp 002 & Phyllanthaceae & 0.39 & 0.60 & 0.08 & 1.07 \\
\hline 11. & Antidesma sp 004 & Phyllanthaceae & 0.39 & 0.60 & 0.16 & 1.15 \\
\hline 12. & Aporosa frutescens Blume & Phyllanthaceae & 0.39 & 0.60 & 0.22 & 1.21 \\
\hline 13. & Aporosa villosa (Lindl.)Baill. & Phyllanthaceae & 1.18 & 1.79 & 1.06 & 4.03 \\
\hline 14. & Archidendron sp 004. & Leguminosae & 0.79 & 0.60 & 0.28 & 1.67 \\
\hline 15. & Artocarpus odoratissimus & Moraceae & & & & \\
\hline & Blanco & & 0.79 & 1.19 & 1.33 & 3.31 \\
\hline 16. & $\begin{array}{l}\text { Barringtonia lanceolata } \\
\text { (Ridl.) Payens }\end{array}$ & Lecythidaceae & 1.18 & 1.79 & 1.47 & 4.44 \\
\hline 17. & Bhesa paniculata Arn. & Centroplacaceae & 2.36 & 2.38 & 1.96 & 6.70 \\
\hline 18. & $\begin{array}{ll}\text { Blumeodendron } & \text { kurzii } \\
\text { (Hook.f.) J.J.Sm.ex } & \text { Koord. }\end{array}$ & Euphorbiaceae & & & & \\
\hline & $\&$ Valeton & & 0.39 & 0.60 & 0.09 & 1.08 \\
\hline 19. & $\begin{array}{l}\text { Canarium patentinervium } \\
\text { Miq. }\end{array}$ & Burseraceae & 0.39 & 0.60 & 0.12 & 1.11 \\
\hline 20. & Canarium sp 001 & Burseraceae & 1.18 & 1.79 & 0.86 & 3.83 \\
\hline 21. & Connarus odoratus Hook .f. & Connaraceae & 0.39 & 0.60 & 0.08 & 1.07 \\
\hline 22. & Cyatochalyx magnifructus & Annonaceae & & & & \\
\hline & R.J.Wang \& R.M.K.Saunders & & 0.39 & 0.60 & 0.05 & 1.04 \\
\hline 23. & Diospyros sp & Ebenaceae & 0.39 & 0.60 & 0.50 & 1.49 \\
\hline 24. & Elaeocarpus mastersii King & Elaeocarpaceae & 1.18 & 1.79 & 0.91 & 3.88 \\
\hline 25. & Elaeocarpus serratus & Elaeocarpaceae & & & & \\
\hline & Linnaeus & & 0.39 & 0.60 & 0.50 & 1.49 \\
\hline 26. & Ficus sp. & Moraceae & 0.39 & 0.60 & 0.91 & 1.90 \\
\hline 27. & Ficus sp 003 & Moraceae & 0.39 & 0.60 & 0.11 & 1.10 \\
\hline 28. & Galearia filiformis (Blume) & Pandaceae & & & & \\
\hline & Boerl. & & 0.39 & 0.60 & 1.80 & 2.79 \\
\hline 29. & Garcinia parvifolia (Miq.) & Clusiaceae & & & & \\
\hline & Miq. & & 3.15 & 2.98 & 3.57 & 9.70 \\
\hline 30. & Ginotroches axillaris Blume & Rhizophoraceae & 0.79 & 1.19 & 0.31 & 2.29 \\
\hline 31. & Gonystylus sp 001 & Thymelaeaceae & 0.39 & 0.60 & 0.23 & 1.22 \\
\hline 32. & $\begin{array}{l}\text { Gymnacranthera } \\
\text { (King) Warb }\end{array}$ & Myristicaceae & 039 & 060 & 0 P & 110 \\
\hline
\end{tabular}




\begin{tabular}{|c|c|c|c|c|c|c|}
\hline 33. & Gymnacranthera sp 001 & Myristicaceae & 1.57 & 1.19 & 1.70 & 4.46 \\
\hline 34. & Ixonanthes icosandra Jack. & Ixonanthaceae & 1.57 & 2.39 & 1.50 & 5.46 \\
\hline \multirow[t]{2}{*}{35.} & Koompassia malaccensis & Leguminosae & & & & \\
\hline & Maingay ex Benth. & & 0.79 & 1.19 & 3.38 & 5.36 \\
\hline 36. & Lindera sp 001 & Lauraceae & 0.79 & 1.19 & 1.82 & 3.80 \\
\hline \multirow{2}{*}{37.} & Lithocarpus bennetii (Miq.) & Fagaceae & & & & \\
\hline & Rehder & & 0.39 & 0.60 & 0.80 & 1.79 \\
\hline 38. & Litsea ferruginea Blume & Lauraceae & 3.15 & 2.38 & 8.03 & 13.56 \\
\hline 39. & Litsea firma (Blume) Hook.f. & Lauraceae & 0.79 & 1.19 & 5.26 & 7.24 \\
\hline 40. & Litsea grandis (Nees) Hook.f. & Lauraceae & 0.79 & 0.60 & 0.68 & 2.07 \\
\hline \multirow[t]{2}{*}{41.} & Litsea monopetala (Roxb.) & Lauraceae & & & & \\
\hline & Pers. & & 1.97 & 1.79 & 0.64 & 4.40 \\
\hline 42. & Litsea sp 002 & Lauraceae & 0.39 & 0.60 & 0.12 & 1.11 \\
\hline 43. & Litsea sp 001 & Lauraceae & 1.39 & 0.60 & 0.06 & 1.05 \\
\hline \multirow{3}{*}{45.} & Memecylon caeruleum Jack. & Melastomataceae & 0.39 & 0.60 & 0.23 & 1.22 \\
\hline & Nephelium ramboutan-ake & Sapindaceae & & & & \\
\hline & (Labill.) Leenh. & & 1.97 & 1.79 & 1.19 & 4.95 \\
\hline 46. & Nephelium cuspidatum Blume & Sapindaceae & 0.79 & 0.60 & 0.24 & 1.63 \\
\hline \multirow[t]{2}{*}{47.} & Ochanostachys & Olacaceae & & & & \\
\hline & Mast. & & 0.79 & 0.60 & 0.64 & 2.03 \\
\hline 48. & Palaquium sp 001 & Sapotaceae & 0.39 & 0.60 & 0.22 & 1.21 \\
\hline \multirow[t]{2}{*}{49.} & Pimelodendron griffithianum & Euphorbiaceae & & & & \\
\hline & (Mull.Arg.) Benth.ex Hook.f. & & 0.39 & 0.60 & 0.61 & 1.60 \\
\hline \multirow[t]{2}{*}{50.} & Popowia pisocarpa (Blume) & Annonaceae & & & & \\
\hline & Endl. Ex Walp. & & 0.39 & 0.60 & 0.09 & 1.08 \\
\hline \multirow[t]{2}{*}{51.} & Porterandia anisophylla (Jack & Rubiaceae & & & & \\
\hline & ex Roxb.) Ridl. & & 2.76 & 2.97 & 1.14 & 6.87 \\
\hline \multirow[t]{2}{*}{52.} & Psychotria viridiflora Reinw. & Rubiaceae & & & & \\
\hline & Ex Blume & & 1.18 & 0.60 & 0.96 & 2.74 \\
\hline 53. & Pternandra sp 001 & Melastomataceae & 0.79 & 0.60 & 0.93 & 2.32 \\
\hline 54. & Santiria griffithii Engl. & Burseraceae & 2.36 & 1.19 & 3.55 & 7.10 \\
\hline 55. & Santiria mollis Engl. & Burseraceae & 0.79 & 0.60 & 1.14 & 2.53 \\
\hline 56. & Santiria rubiginosa Blume & Burseraceae & 0.79 & 0.60 & 0.63 & 2.02 \\
\hline 57. & Santiria tomentosa Blume & Burseraceae & 0.39 & 0.60 & 1.34 & 2.33 \\
\hline 58. & Santiria laevigata Blume & Burseraceae & 0.39 & 0.60 & 0.37 & 1.36 \\
\hline 59 & Shorea leprosula Miq. & Dipterocarpaceae & 0.79 & 0.60 & 0.11 & 1.50 \\
\hline 60. & Shorea parvifolia Dyer & Dipterocarpaceae & 0.79 & 0.60 & 0.09 & 1.48 \\
\hline 61. & Sindora coriacea Baker) Prain & Leguminosae & 0.79 & 0.60 & 1.51 & 2.90 \\
\hline 62. & Strombosia javanica Blume & Olacacea & 1.18 & 0.60 & 0.38 & 2.16 \\
\hline 63. & Swietenia macrophylla King & Meliacea & 1.18 & 0.60 & 0.72 & 2.50 \\
\hline 64. & Symplocos sp 001 & Symplocaceae & 0.39 & 0.60 & 0.19 & 1.18 \\
\hline \multirow[t]{2}{*}{65.} & Syzygium acuminatissimum & Myrtaceae & & & & \\
\hline & (King) Merr. \& L.M. Perry & & 0.39 & 0.60 & 3.32 & 4.31 \\
\hline 66. & Syzygium attenuatum & Myrtaceae & 0.79 & 0.60 & 0.33 & 1.72 \\
\hline 67. & Syzygium garciniifolium & Myrtaceae & 0.39 & 0.60 & 0.06 & 1.04 \\
\hline 68 & Syzygium sp 002 & Myrtaceae & 0.79 & 0.60 & 0.73 & 2.10 \\
\hline 69 & Syzygium sp 001 & Myrtaceae & 0.79 & 1.19 & 3.88 & 5.85 \\
\hline \multirow[t]{2}{*}{70} & Timonius flavescens (Jacg.) & Rubiaceae & & & & \\
\hline & Baker & & 0.39 & 0.60 & 0.06 & 1.05 \\
\hline \multirow[t]{2}{*}{71} & wallichianus & Rubiaceae & & & & \\
\hline & (Korth.) Valeton & & 0.39 & 0.60 & 0.11 & 1.10 \\
\hline 72. & Eugenia sp & Myrtaceae & 0.39 & 0.60 & 0.73 & 1.72 \\
\hline \multirow[t]{2}{*}{73.} & Macaranga gigantea (Reichb.f & Euphorbiaceae & & & & \\
\hline & \& Zoll.) Mull.Arg. & & 0.39 & 0.60 & 0.13 & 1.12 \\
\hline 74 & Syzygium sp 003 & Myrtaceae & 0.39 & 0.60 & 0.32 & 1.31 \\
\hline 75. & Unidentified & Centroplacaceae & 0.39 & 0.60 & 1.18 & 2.17 \\
\hline 76. & Unidentified & Myrtaceae & 0.39 & 0.60 & 0.18 & 1.17 \\
\hline
\end{tabular}




\begin{tabular}{|c|c|c|c|c|c|c|}
\hline 77 & Unidentified & Rubiaceae & 0.39 & 0.60 & 0.10 & 1.09 \\
\hline 78. & Garcinia sp 001 & Clusiaceae & 0.39 & 0.60 & 0.18 & 1.17 \\
\hline 79 & Cratoxylon sumatranum (Jack) & Hypericacea & & & & \\
\hline & $B L$. & & 0.79 & 1.19 & 0.28 & 2.26 \\
\hline 80 & Urophyllum arboreum Reinw. & Rubiaceae & & & & \\
\hline & Ex Blume Korth & & 0.39 & 0.60 & 0.32 & 1.31 \\
\hline 81. & Vitex sp001 & Lamiaceae & 0.39 & 0.60 & 0.16 & 1.15 \\
\hline 82 & $\begin{array}{l}\text { Xanthophyllum } \\
\text { Roxb. }\end{array}$ & Polygalaceae & 0.39 & 0.60 & 0.28 & 1.27 \\
\hline
\end{tabular}

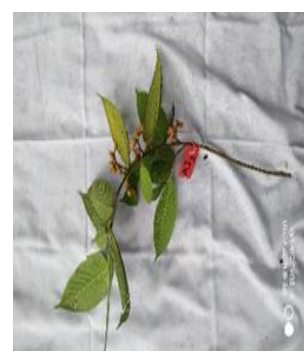

a. Gironniera nervosa

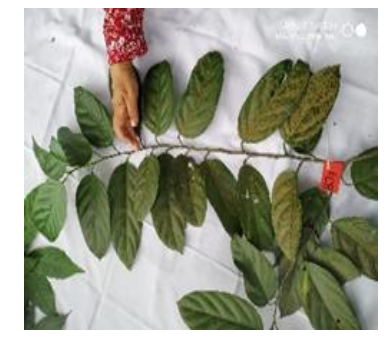

e. Ochanostachys amentaceae

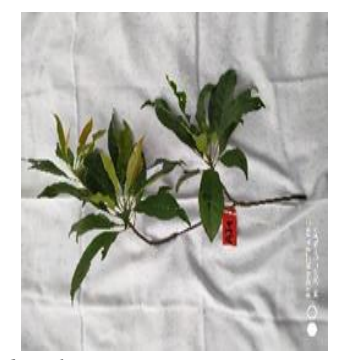

b.Elaeocarpus mastersii

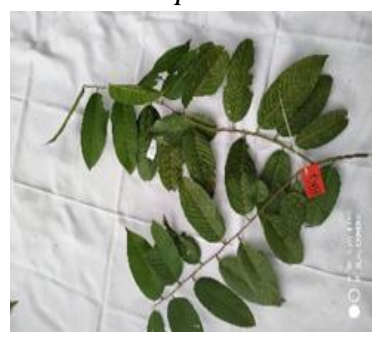

f. Shorea leprosula

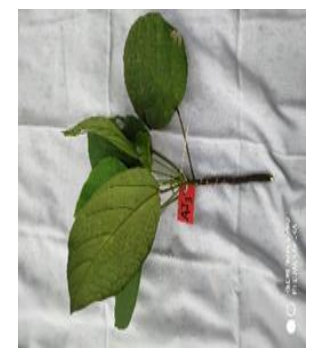

c.Endospermum diadenum

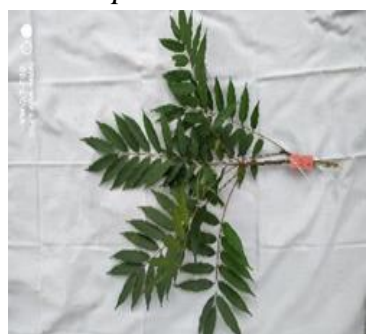

g. Santiria griffithii

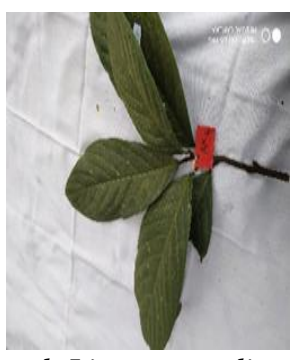

d. Litsea grandis

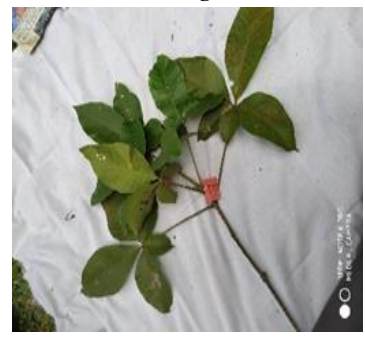

h. Vitex pinnata

Figure 1. Several types of trees in Education Forest of Jambi Mendalo University

(Source : Nursanti dan Hardiyanti, 2020)

Table 2. Association value and association coefficient between dominant tree species in HPUJM

\begin{tabular}{|c|c|c|c|c|c|c|}
\hline \multirow[t]{2}{*}{ No } & \multirow[t]{2}{*}{ Latin name } & \multicolumn{2}{|c|}{$\mathrm{X}^{2}$ Table } & \multirow[t]{2}{*}{$\mathrm{X}^{2}$ Count } & \multirow[t]{2}{*}{ Association } & \multirow[t]{2}{*}{ Jaccard Index } \\
\hline & & $5 \%$ & $1 \%$ & & & \\
\hline 1. & A.scholaris and A. lucida & 3.84 & 6.63 & 0.18 & Not significant & 0.31 \\
\hline 2. & A.scholaris and E.diadenum & 3.84 & 6.63 & 0.00 & Not significant & 0.21 \\
\hline 3. & A.scholaris and G.nervosa & 3.84 & 6.63 & 0.00 & Not significant & 0.21 \\
\hline 4. & A.scholaris and R.cinerea & 3.84 & 6.63 & 2.90 & Not significant & 0.36 \\
\hline 5. & A.scholaris and V.pinnata & 3.84 & 6.63 & 1.63 & Not significant & 0.33 \\
\hline 6. & A.lucida and E,diadenun & 3.84 & 6.63 & 3.00 & Not significant & 0.11 \\
\hline 7. & A.lucida and G.nervosa & 3.84 & 6.63 & 0.00 & Not significant & 0.25 \\
\hline 8. & A.lucida and R.cinerea & 3.84 & 6.63 & 0.89 & Not significant & 0.29 \\
\hline 10. & A.lucida and V.pinnata & 3.84 & 6.63 & 5.04 & - $\quad+$ & 0.46 \\
\hline 11. & E.diadenum and G.nervosa & 3.84 & 6.63 & 2.34 & Not significant & 0.07 \\
\hline 12. & E.diadenum and R.cinerea & 3.84 & 6.63 & 0.00 & Not significant & 0.17 \\
\hline 13. & E.diadenum and V.pinnata & 3.84 & 6.63 & 4.94 & $\bullet-$ & 0.00 \\
\hline 14. & G.nervosa and R.cinerea & 3.84 & 6.63 & 1.00 & Not significant & 0.08 \\
\hline 15. & G.nervosa and V.pinnata & 3.84 & 6.63 & 2.52 & Not significant & 0.36 \\
\hline 16 & L. ferruginea and A.scholaris & 3.84 & 6.63 & 0.32 & Not significant & 0.18 \\
\hline 17 & L. ferruginea and A. lucida & 3.84 & 6.63 & 1.2 & Not significant & 0.20 \\
\hline 18 & L. ferruginea and E,diadenun & 3.84 & 6.63 & 2.4 & Not significant & 0 \\
\hline 19 & L. ferruginea and G. nervosa & 3.84 & 6.63 & 9.6 & $* *+$ & 0.50 \\
\hline 20 & L. ferruginea and R.cinerea & 3.84 & 6.63 & 0 & Not significant & 0.10 \\
\hline 21 & L. ferruginea and V.pinnata & 3.84 & 6.63 & 11.6 & $* * \quad-$ & 0.20 \\
\hline
\end{tabular}

Source : Primary data processing, 2020

Description : + : positive association, - : negative association, $\bullet:$ significantly different at the test level of $5 \%$, **: $\quad$ significantly different at the test level of $1 \%$ 
E. diadenum was the dominant tree in HPUJM with the highest IVI reaching $17.09 \%$. This species also had the highest relative dominance according to the morphological character of the trunk as a tree with medium to large diameter. The crown of E. diadenum is slightly rounded wide with large branches. It also has single oval leaf that is wider at the base. The local name of E. diadenum in Jambi Province is medang labu, kayu $l a b u$, or medang sendok. This tree is a source of commercial timber under the trade name 'Sesendok' which is harvested for local or commercial use. According to Suhartati et al., 2012 E. diadenum or medang labu generally grows in old secondary forest or in open spaces in primary forest, on sandy and dry soil or slightly calcareous white sandy clay. This species is a pioneer species in former fields and logged forest, and grows very fast in places with showering sun light.

Ecologically, the association between two types of plants originates from growing together in the same ecological niche. This indicates that association is not absolutely influenced by the density of each species, but by many other factors, which may provide random effects. Association can occur because the physiological and morphological suitability of a plant with other plants, but it can also occur because physical factors of the habitat such as the need for shade, microclimate such as light and temperature (Sirami et al., 2016).

The results show that from the 21 dominant tree combinations, there were only 4 positive associated combinations, sucha as association between A. lucida and $V$. pinnata, E. diadenum and V. pinnata, L. ferrginea and G. nervosa, L. ferruginea and V. pinnata, A. lucida and $V$. pinnata, as well as $L$. ferruginea and $G$. nervosa. It means that the two trees always present together spatially and adapt to each other (Barbour et al., 1987). It also shows that the two species can live together and are dependent on one another. The togetherness of the two types is because they have the same or almost the same responses to extreme changes in environmental factors.

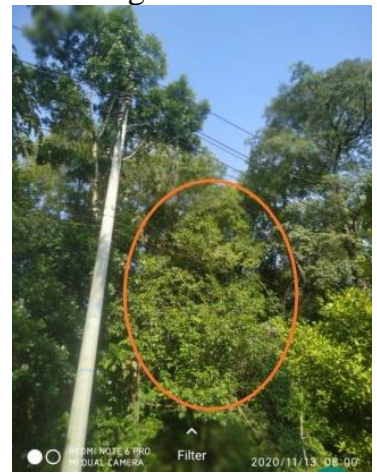

Figure a

Figure 2. a) V. pinnata and b). E. diadenum in Education Forest of Jambi University

(Source: Nursanti dan Hardiyanti, 2020)
Based on the results of the study, the opportunities of $A$. lucida and $V$. pinnata as well as the oportunities of $L$. feruginea and $G$. nervosa to be planted and grown together in one very large area is greater. This is because both types have the potential to produce a positive relationship between one species and another. The positive association between the two types of trees occurs due to several possibilities. The research results by Windusari et al., 2011 shows that the association between the two tree species is because the two tree species like places with almost the same environmental parameters, for example, they like wet habitats or habitats with high sunlight intensity. It is further explained that species association can affect species diversity in successional forests.

In addition to combinations with positive associations, there were also dominant tree combinations with negative associations between E.diadenum and V.pinnata, as well as between L.ferruginea and $V$. pinnata. According to Whittaker (1975) negative association indicates that the species are less likely to be found together or cannot want to live side by side. Another suggestion is that the negative association is caused by environmental modifications and certain types producing toxins. Sofiah et al., 2013 explained that species pairs do not always result in a positive association. Pratama et al., (2012) stated that negative association shows a lack of tolerance for living together in the same area, or the absence of mutually beneficial relationships, especially in the division of growth space. E. diadenum is a fast-growing tree species from the Euphorbiaceae family with slightly rounded crowns (Figure 2b), while $V$. pinnata is an intolerant tree species or requires light but slow growth (Figure $2 \mathrm{a}$ ). $\mathrm{V}$. pinnata seeds cannot germinate under shade. Ecological and morphological characteristics of $V$. pinnata cannot tolerate the morphological characteristics of fast-growing E. diadenum whose crowns can grow quickly to create shade.

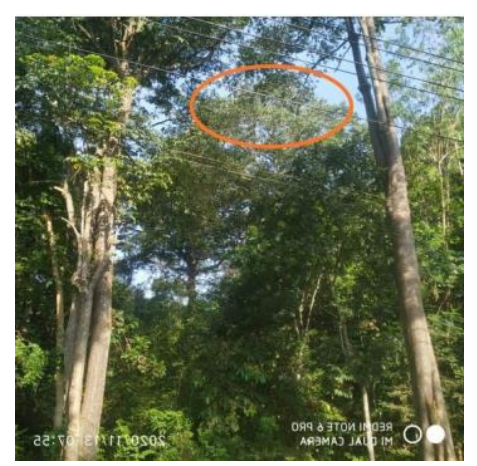

Figure b

(Source: Nursanti dan Hardiyanti, 2020) 
Based on the results of the study, there were 17 combinations of dominant tree species that were not associated. The existence of tree species is not associated with other plants because the presence of these species is not influenced by the presence of other species, and these plants have a high tolerance for various environmental conditions. In this study, A. scholaris is not associated with other dominant tree species in HPUJM. This result supports the previous research data by Hidayat and Juhaeti (2013) who stated that the A. scholaris in Ujung Kulon National Park is not associated with other tree species composing its habitat. It shows that A. scholaris is a species that is resistant to various habitat conditions.

\section{CONCLUSION}

The results of the study showed that from 21 dominant tree combination in HPUJM, there were only 4 combinations with significance association ; they were $A$. lucida and $V$. pinnata with positive association, $E$. diadenum and $V$. pinnata with negative association, $L$. ferruginea and $G$. nervosa with positive association, and the last was L. ferruginea and V.pinnata with negative association.

\section{REFERENCES}

Barbour MG, Burk JH, Pitts, WD Pitts. 1987. Terrestrial Plant Ecology $2^{\text {nd }}$ Ed. 157. The Benjamin/Cummings. New York

Clark DB, Palmer MW, Clark DA. 1999. Edaphic factors and the landscape-scale distributions of tropical rain forest trees. Ecology. 80(8): 2662-2675.

Greig-Smith P. 1983. Quantitative Plant Ecology. Oxpord: Blackwell Scientific.

Hidayat S, Juhaeti T. 2013. Asosiasi Alstonia spp di Taman Nasional Ujung Kulon. Bionatura-Jurnal Ilmu-Ilmu Hayati dan fisik. 15(1):44-48.

Ludwig JA, Reynolds JF. 1988. Statistical Ecology. 2nd ed. London: Edward Arnold (Publisher) Co. Ltd.

McNaughton SJ, Wolf WL. 1992. Ekologi Umum. Edisi Kedua. Penerjemah: Sunaryono P. dan Srigandono. Penyunting: Soedarsono. Yogyakarta: Gadjah Mada Univ. Press.

Nursanti, Hardiyanti, RA. 2020. Struktur dan komposisi vegetasi pada plot permanen di Hutan Kampus Universitas Jambi. Jurnal Silva Tropika. 4(1): 262-279
Nursanti, Swari EI. 2013. Potensi keanekaragaman hayati, iklim mikro dan serapan karbon pada ruang terbuka hijau Kampus Mendalo Universitas Jambi. Bioplant 2(2): 101-112.

Partomihardjo T, Arifian D, Pratama BA, Mahyuni R. 2004. Jenis-Jenis Pohon Penting di Hutan Nusakambangan. Jakarta: LIPI Press.

Pratama BA, Alhamd L, Rahajoe JS. 2012. Asosiasi dan karakterisasi tegakan pada Hutan Rawa Gambut di Hampagen, Kalimantan Tengah. Jurnal Teknologi Lingkungan. 2012: 69-76.

Putra ME. 2016. Jenis dan kelimpahan burung di Kawasan Kampus Pinang Masak Mendalo Darat Universitas Jambi. Jambi: Universitas Jambi.

Rugayah EA, Widjaja E, Pratiwi. 2005. Pedoman Pengumpulan Data Keanekaragaman Flora. Bogor: Pusat Penelitian Biologi LIPI.

Sirami EV, Marsono D, Sadono R, Imron MA. 2016. Struktur, keragaman dan asosiasi komunitas tumbuhan pemanjat dengan populasi alami merbau di Taman Wisata Alam Gunung Meja Manokwari Papua Barat. Jurnal Manusia dan Lingkungan, 23 (1) (1), 82-91.

Soerianegara I, Indrawan A. 2002. Ekologi Hutan Indonesia. Bogor: Laboratorium Ekologi Hutan. Fakultas Kehutanan. IPB.

Sofiah S, Setiadi D, Widyatmoko D. 2013. Pola penyebaran kelimpahan, dan asosiasi bamboo pada Kumunitas Tumbuhan di Taman Wisata Alam Gunung Baung Jawa Timur. Berita Biologi. Jurnal Ilmu ilmu Hayati. 12(2): 239-247.

Subagyo A, Arfan E, Siburian J. 2008. Pola aktivitas harian lutung (Presbytis cristata) di Hutan Kampus Pinang Masak Universitas Jambi. Biospecies 1 (1): 6-10.

Suhartati, Syofia R, Ahmad J, Nurrahman E. 2012. Sebaran dan persyaratan tumbuh jenis alternatif kayu pulp. Jakarta: Badan Penelitian dan Pengembangan Kehutanan. .

Whittaker RH. 1975. Communities and Ecosystems. $2^{\text {nd }}$ Revise Edition. New York: MacMillan Publishing Co.

Windusari Y, Susanto RH, Dahlan Z, Susetyo W. 2011. Asosiasi Jenis pada Komunitas Vegetasi Suksesi di Kawasan Pengendapan Tailing Tanggul Ganda di Pertambangan PTFI Papua. Jurnal Ilmiah IlmuIlmu Hayati Biota. 16(2): 242-252. 